\title{
Efficacy of Post-emergence Herbicides Applied at Reduced Doses on Weeds in Durum Wheat (Triticum durum L.) in Central Greece
}

\author{
Anestis KARKANIS ${ }^{1}$, Dimitrios BILALIS ${ }^{2 *}$, Aspasia EFTHIMIADOU ${ }^{3}$ \\ Agapi GAVALAKI ${ }^{2)}$, Nikolaos KOUSTAS ${ }^{2}$ \\ ${ }^{1)}$ Department of Agriculture Crop Production and Rural Environment, University of Thessaly, Fytokou \\ Str, 38446, Nea Ionia, Magnesia, Greece. \\ ${ }^{2)}$ Department of Crop Production, Agriculture University of Athens, Iera Odos 75, 11855 Athens, \\ Greece. \\ ${ }^{3)}$ Dean of Postgraduates, New York College, Athens, Greece. \\ ${ }^{*}{ }^{*}$ )Coresponding author, e-mail: bilalisdimitrios@yahoo.gr
}

Bulletin UASVM Horticulture 71(2) / 2014

Print ISSN 1843-5254, Electronic ISSN 1843-5394

DOI:10.15835/buasvmcn-hort:10413

\begin{abstract}
A field experiment was conducted to determine the effects of post-emergence herbicides applied at the recommended and reduced doses on weeds in durum wheat. A randomized complete block design was employed with 4 replications per treatment. Weed density differed significantly among the herbicide treatments. Our results show that the herbicides could effectively control A. sterilis, A. myosuroides and G. aparine when their doses were reduced by $15 \%$. The herbicides pyroxsulam and mesosulfuron-methyl+iodosulfuron-methyl-sodium showed some difficulties in controlling S. arvensis even at the labeled recommended dose.
\end{abstract}

Keywords: dose reduction, herbicides, control, weeds, wheat.

Introduction. Research studies have indicated that there is good potential to utilize reduced herbicide doses within a competitive cropping system (i.e. competitive cultivars, higher crop seed rates and reduced row spacing) (Blackshaw et al., 2006). Travlos (2012) also reported that the best weed control in wheat crop was achieved with the highest herbicide rate, but lower rates of mesosulfuron+iodosulfuron often provided adequate weed control.

Aims and objectives. The aim of this study was to determine the effects of post-emergence herbicides applied at the recommended and reduced doses on Avena sterilis, Alopecurus myosuroides, Galium aparine and Sinapis arvensis population reduction, on photosynthetic rate and seed yield of wheat crop.

Materials and methods. Field experiment was carried out in central Greece(Domokos, $230 \mathrm{~km}$ from Athens, $22.33 \mathrm{E}$ and $39.03 \mathrm{~N}$ ) in 2013-2014. Thisstudy was supported by Research Committee of
University of Thessaly. The wheat (Triticum durum cv. Quadrato) was sown on 10 November 2013. The post-emergence herbicides pinoxaden $(10 \%)$ (Axial EC), 2.4 D (45.25\%) + florasulam (0.625\%) (Mustang EC), pyroxsulam (7.5\%) (Senior WG) and mesosulfuron-methyl (3\%)+iodosulfuronmethyl-sodium (3\%) (Hussar maxx WG) were used in the experiment. The recommended doses of pinoxaden, 2.4 D+florasulam, pyroxsulam and mesosulfuron-methyl+iodosulfuron-methylsodium were $400 \mathrm{ml} \mathrm{ha}^{-1}, 600 \mathrm{ml} \mathrm{ha}^{-1}, 200 \mathrm{~g} \mathrm{ha}^{-1}$ and $200 \mathrm{~g} \mathrm{ha}^{-1}$, respectively. The herbicides were applied at wheat tillering (22 March 2014) at the rates of recommended dose $(\mathrm{X}), 0.85 \mathrm{X}$ and $0.70 \mathrm{X}$. A randomized complete block design was employed with 4 replications per treatment. The herbicides treatments included untreated control, pinoxaden+2.4D+florasulam (PIN), pyroxsulam (PYR) and mesosulfuron-methyl+iodosulfuronmethyl-sodium (MES) at three doses. The experiment was set up over an area of $600 \mathrm{~m}^{2}$. The 
Tab. 1. Effect of different herbicides treatments on weed population reduction (\%), photosynthetic rate $\left(\mu \mathrm{mol} \mathrm{CO} \mathrm{m}^{-2} \mathrm{~s}^{-1}\right)$ and seed yield $\left(\mathrm{kg} \mathrm{ha}^{-1}\right)$ of wheat crop.

\begin{tabular}{cccccccccccc}
\hline & \multirow{2}{*}{ Control } & \multirow{2}{*}{ PIN X } & PIN & PIN & PYR & PYR & PYR & MES & MES & MES & LSD \\
& & $0.85 \mathrm{X}$ & $0.7 \mathrm{X}$ & $\mathrm{X}$ & $0.85 \mathrm{X}$ & $0.7 \mathrm{X}$ & $\mathrm{X}$ & $0.85 \mathrm{X}$ & $0.7 \mathrm{X}$ & $5 \%$ \\
\hline A. sterilis & 0 & 90 & 77 & 15 & 86 & 81 & 9 & 88 & 79 & 19 & 9.59 \\
A. myosuroides & 0 & 87 & 79 & 9 & 83 & 70 & 12 & 87 & 75 & 13 & 13.10 \\
G. aparine & 0 & 98 & 70 & 13 & 85 & 48 & 6 & 81 & 64 & 11 & 10.00 \\
S. arvensis & 0 & 85 & 63 & 23 & 73 & 47 & 24 & 45 & 27 & 14 & 19.18 \\
Seed yield & 2200 & 5390 & 4940 & 3130 & 5350 & 4670 & 2580 & 5190 & 4590 & 2470 & 320.9 \\
$\quad$ P. rate & 8.84 & 16.60 & 15.97 & 9.80 & 15.8 & 15.08 & 9.18 & 15.4 & 9.79 & 9.39 & 1.29 \\
\hline
\end{tabular}

plot size was $3 \times 5 \mathrm{~m}$. The number of the dominant weeds and the photosynthetic rate of wheat plants were assessed 40 days after herbicides application. The wheat seed yield was determined on 28 June 2014. For analysis of variance and comparisons of means, the software SigmaPlot 12 was used. The LSD test was used to detect and separate the mean treatment differences.

Results and discussion. The main weeds present in the experiment were Avena sterilis, Alopecurus myosuroides, Galium aparine and Sinapis arvensis. Weed density differed significantly among the herbicide treatments (Tab. 1). Our results show that the herbicides could effectively control $A$. sterilis, $A$. myosuroides and $G$. aparine when their doses were reduced by $15 \%$. The herbicides pyroxsulam and mesosulfuronmethyl+iodosulfuron-methyl-sodium showed some difficulties in controlling $S$. arvensis even at the labeled recommended dose. Barros et al. (2007) also observed that using lower doses than recommended the herbicide mesosulfuron-methyl and iodosulfuron-methyl-sodium controls the annual grass weeds (A. sterilis and Lolium rigidum) better than some broad-leaved weeds. Moreover, our results indicated that the lowest seed yield and photosynthetic rate of wheat crop were recorded for weedy control treatment. The wheat seed yield had negative and significant correlation with total weed density $(\mathrm{r}=-0.958, \mathrm{p}<0.001)$.

Conclusion. Our results show that the herbicides could effectively control A. sterilis, $A$. myosuroides and G. aparine when their doses were reduced by $15 \%$. The grain yield and photosynthetic rate of wheat crop decreased when herbicides doses was reduced. The highest seed yield was found in PINX treatment.

\section{REFERENCES}

1. Barros JFC, Basch G, de Carvalho M (2007). Effect of reduced doses of a post-emergence herbicide to control grass and broad-leaved weeds in no-till wheat under Mediterranean conditions. Crop Prot 26: 1538-1545.

2. Blackshaw RE, O’Donovan JT, Harker KN, Clayton GW, Stougaard RN (2006). Reduced herbicide doses in field crops: A review. Weed Biol Manag 6: 10-17.

3. Travlos IS (2012). Reduced herbicide rates for an effective weed control in competitive wheat. Int J Plant Prod 6: $1-14$. 